\title{
Missing data treatment method on cluster analysis
}

\author{
Elsiddig Elsadig Mohamed Koko *, Amin Ibrahim Adam Mohamed \\ Sudan University of Science \& Technology, Faculty of science, Department of Statistics \\ *Corresponding author E-mail: siddiggt@gmail.com
}

Copyright () 2015 Elsiddig Elsadig Mohamed Koko, Amin Ibrahim Adam Mohamed. This is an open access article distributed under the Creative Commons Attribution License, which permits unrestricted use, distribution, and reproduction in any medium, provided the original work is properly cited.

\begin{abstract}
The missing data in household health survey was challenged for the researcher because of incomplete analysis. The statistical tool cluster analysis methodology implemented in the collected data of Sudan's household health survey in 2006.

Current research specifically focuses on the data analysis as the objective is to deal with the missing values in cluster analysis. Two-Step Cluster Analysis is applied in which each participant is classified into one of the identified pattern and the optimal number of classes is determined using SPSS Statistics/IBM. However, the risk of over-fitting of the data must be considered because cluster analysis is a multivariable statistical technique. Any observation with missing data is excluded in the Cluster Analysis because like multi-variable statistical techniques. Therefore, before performing the cluster analysis, missing values will be imputed using multiple imputations (SPSS Statistics/IBM). The clustering results will be displayed in tables. The descriptive statistics and cluster frequencies will be produced for the final cluster model, while the information criterion table will display results for a range of cluster solutions.
\end{abstract}

Keywords: Cluster Analysis; Missing Data; Multiple Imputation Method; Sudan Household Health Survey (SHHS).

\section{Introduction}

It could be very tedious for any researcher to make an analysis of incomplete data. In any research, data plays a significant role from every aspect. When the researchers had performed household health survey in Sudan County, they faced many problems because the people were not interested to provide their health data. Basically, an epidemics diseases had scattered in Sudan, due to which many people had died, which affected by the people. Due to this the household health survey program was commenced for inspecting the affected people and cause of this epidemic disease (see [1]).

\subsection{Missing data}

The incomplete data was insignificant for the analysis of research, so they left a negative effect on the data treatment methods. Since different missing data patterns may require different imputation methods, we studied the missing pattern of the datasets before selecting an appropriate imputation method. As first introduced by [2].

\subsection{Criticism on data collection of household health surveys}

Household surveys performed by World Health Organisation (WHO) are often criticized for estimation of missing observations ([4], [5] and [3]) and for the methodology for information collection ([6]; [7]). Biasness in the information is also found in much criticism, including the use of too small data for too many imputations, use of limited number of questions out of a large number of questions for indexing, inadequacy of the sample to represent the population, inherent flaws in method, and majority of key informants being the people of $\mathrm{WHO}[5]$. 


\subsection{Sudan household health survey (SHHS)}

The Sudan household health survey was conducted in the year 2006. The household survey executed by Central Bureau of Statistics of Sudan and Federal Health Ministry department representing the two other health-related department. This survey was scientifically and monetary supported by UNICEF and Pan Arab health project organization. The Sudan household health survey accumulated the hard work of all the health-related agencies to perform a unanimous survey that has fulfill the interests of all stakeholders as it was a mixture of analyzing the multiple factors that were announcing the scarcity in Sudan such as, food safety, medicines and other health-related factors. The strategy and the execution of SHHS such as technical, working group, steering and coordination body. It was started with the targeted objective, to complete all the related information or statistics about the Sudan people affected data. It could be beneficial for the agencies which were prevailing under the health issues [42].

Design of the sample for the Sudan Household Health Survey (SHHS) provided estimates on a large number of indicators on the basic health situation at the national level and for 25 States. The target universe for the SHHS included the population living in individual households and the nomadic population camping at a location/place at the time of the survey.

\section{Methods}

\subsection{Missing data treatment}

Every real world study frequently faces the complication of missing data. From chances to the design, there are numerous factors that result in missing data. The situations leading to missing data often occur as some participants in a study try to protect confidentiality and purposely excise information; to provide values some subjects may decline, and some variables may not be collected from all subjects. A potentially biased as well as an inefficient method of complete case in which the subjects with missing observations are dropped, is frequently used despite its disadvantages. Many researchers have been trying to find the efficient and appropriate method for analysing the data with missing values. A large number of values with missing data might lead by few missing data points in each covariate thus many real-world settings require the models that incorporate predictors observed partially.

Multiple imputation has been primarily focused in real-world settings in the comprehensive overviews provided by [8], [9], and [5]. Though the work is somewhat dated, maximum likelihood approach of [10] was included in the hierarchy of approaches to deal with the missing predictors described by [11].

\subsection{1. "Ad-hoc" methods}

Missing data are found to be addressed by a series of "ad-hoc" methods. One approach for continuous involves creation of a new variable that indicates the missing data, recoding missing observations to some common value, and then including the interaction between these variables and the variables themselves in the model. Creation of new variables for missing data holds for categorical variable too. These ad-hoc approaches are not recommended due to the potential induction of biasness ([12]; [13]). Another approach is to drop those subjects from the analysis which lack information for many variables. This approach is also not attractive as it often results in unnecessary large standard errors, consequent biasness, and exclusion of important variables. Two other non-recommended methods that have large variability and potential of inducing biasness are found in the work of [14], [15] and [16]. These methods impute missing values through using the last observed value (also known as last observation carried forward LOCF or last value carried forward LVCF) for longitudinal analysis and the average of observed values that is mean imputation.

\subsubsection{Multiple imputations}

[17] Describes the reasons for using a three-step approach, multiple imputations, in estimation of models with incomplete data. First reason is the uncertainty about the non-response model reflected by the creation of plausible values for missing values. Missing observations are then imputed or filled out by these plausible values. A number of completed data set is created through this process repeatedly. Second reason is the availability of complete data methods for analysing the data sets. The last but not least reason is the handling of uncertainty regarding the imputation allowing by combined results.

A public survey data was the first setting to use the method of multiple imputations. Inclusion of detailed and confidential information in a model can be created as auxiliary information, which is unsuitable to include in the public data set. Hence, in survey data settings, multiple imputation remains ideally suited [18]. Each of that data sets can be analysed through the utilization of existing software provided the complete data sets. However, in a setting where a single person is the imputer and the analyst, multiple imputations is more commonly used [19] and [20].

The potential of bias arises from the misspecification of the model; hence the suitable specification of the model of imputation is the key issue for an analyst. Estimation of multivariate mode only needs the variance-covariance matrix and mean vector. Therefore, this computationally traceable model has been used very often. Biasness in result and 
complications in analysis often occur when some of the variables are not Gaussian, in such situation multiple imputation is used [21]. Complication in joint distribution due to missing values in multiple continuous and categorical variables is a salient reason for using multiple imputations. However, the model for analysis must not be richer than the one used for imputation [2]. Following is the description of a number of methods that were found in the literature reviewed.

In addition to the aforementioned imputation methods which replace each missing value with one value, the multiple imputations (MI) by [2] replaces each missing value with a set of plausible values that represent the uncertainty of the correct value.

\subsubsection{Conditional Gaussian}

[22] Improved the Conditional Gaussian approach of imputation for both discrete and continuous missing values. Cases of continuous variables assume a multivariate normal distribution and cases of discrete variables assume a log-linear model [23]. In real-world of multiple categorical variables, a proliferation of parameters can be led by the fit of this general location model as saturated multinomial with shared covariance and separate means (as pointed in [24]. This resulted in the need of simplified log-linear model in practice. S-Plus missing data library and Schafer's mix program (assuming a form of monotonicity) has been implementing this approach.

\subsubsection{Methods of weighting}

The approach of weighting methods used to account missing predictor data (as pointed in [25] and [26]. Complete cases use weights in this approach, which are actually the probabilities obtained through fitting a model for the probability of missingness. Software such as SAS, SUDAAN, SPSS, or Stata that allows for weights can be used to fit weighting approaches.

The general formula for a sample design weight is arithmetically very simple; it is 1 divided by the probability of selection due to the survey design. However, these are usually scaled, so we define the weight as proportional to this number. For example, if there are 3 adults in a given household, the resulting sample design weight for the single interviewed adult will be proportional to $1 /(1 / 3)$, i.e. proportional to 3 . In a one adult household, the weight will be simple proportional to $1 / 1$, i.e. proportional to one. In other words, the influence of the former respondent is being increased threefold relative to the influence of the latter respondent to exactly compensate for the fact the former respondent was three times less likely to be included in the sample.

\subsubsection{Chained equations}

Chain equations are used in an alternative variable-by-variable approach [27] and [28]. Other variables are involved as predictors in the separate specification of each variable in this imputation model. An imputation is generated for the missing variable at each stage of the algorithm then the next variable is imputed using the previous this imputed value. The process reaches convergence at last after the repetition of the Gibbs sampling procedure to impute the missing values. Multiple imputations are generated using separate chains. Predictive matching (where the value from one the nearest set of observed value in the data set is taken by the imputed variables) or a linear regression model is involved in the model for continuous variables. For categorical variables, polytomous models are needed and logistic regression can be fit for dichotomous variables. Are Impute (for R and S-Plus), IVE ware (for SAS or standalone), ICE (for Stata), or MICE library (for R and S-Plus) can provide the implementations of the chained equation approach.

[28] Describes the problem with the approach of chained equation approach as its inability to converge to a sensible stationary distribution where multivariate distributions and separate variables are not compatible though [27] obtained reasonable imputations in a series of studies on simulation even with incompatible separate models. Further establishment of the validity of this approach needs additional work.

\subsubsection{Bayesian approaches}

Posterior distribution sampling of interest is involved in Bayesian framework. Bayesian methods have been more generally applied while multiple imputations were obtained within a Bayesian framework. The close relationship between MI and ML methods and the Bayesian approach estimates the covariates with a prior distribution as described [29]. Estimation of relationships requires a model with a package like WinBugs and specific coding of prior distributions partly due to the flexibility of these methods.

\subsection{Cluster analysis}

\subsubsection{What is a cluster?}


A formal definition of cluster is hard to give despite of the easy visual recognition of clusters from a two-dimensional view. The lack of formal and universal definition of cluster is addressed by many authors with the contribution in the literature of clustering. However, giving one definition is regarded as an intractable problem by the authors [30] and [31]. The weakly defined notion of a cluster depends on the application [32]. The definition is also affected by the goal of cluster analysis. There are different sizes and shapes of clusters depending on the application. Moreover, due to dependency on the resolution, one is looking in the data (global versus local); even the number of inherent clusters in the data is not unambiguous [32].

Typically, strong internal similarities are possessed in data description in terms of clusters yielded from clustering methods [33]. External isolation (separation) and internal cohesion (homogeneity) are often used to define cluster. Hence the definition of cluster is a set of objects dissimilar to the objects in the other clusters but similar to the objects within the same cluster [34].

\subsubsection{Missing data in cluster analysis}

In describing the two alternative approaches of handling missing values; marginalization were missing values are ignored and imputation were estimated values are used to fill in missing values [12] did not consider imputation as a reliable approach in comparison with actually observed data.

Therefore, there is no universally best algorithm for clustering [20]. The best understanding of data set can be obtained when several cluster algorithms are tried [35]. Contributions made by engineers [37], social scientists [38], statisticians [36], biologists [39] and psychologists [40] show that the development of clustering methods is interdisciplinary.

\subsubsection{Two-step cluster analysis}

Reasons for choosing Two-Step Cluster Analysis are the shorter learning curve of Two-Step Cluster Analysis than the alternative approaches method of this analysis readily available in the basic version of SPSS base on the probability. However, method selection is also guided by some head-to-head comparisons of these approaches of cluster analysis. The natural groupings (or clusters) that are usually not apparent will be revealed by the design of the exploratory tool and procedure of Two-Step Cluster Analysis.

\subsubsection{Assumptions of data in two-step cluster analysis}

Both categorical and continuous variables can be analysed through this procedure. Clustering is based on attributes that are represented by variables while objects to be clustered are presented by cases. Variables in the cluster model are assumed to be independent likelihood distance measure. The procedure also assumes that each categorical variable follows a multinomial distribution while each continuous variable follows a normal distribution known as Gaussian distribution. Fair robustness of the procedure in case of violation of both the distributional assumption and the assumption of independence is indicated by the empirical internal testing, but the researcher must be well aware whether these assumptions are met or not. Standardized continuous variables are applicable for the clustering algorithm. SPSS Statistics/IBM provides the option of "To be Standardized" for those continuous variables that are not standardized.

\subsubsection{Suggestions for analyzing survey data}

As pointed in (41) suggested that analysis of survey data is based on assumption if it ignores the weights and the sample design. The weights for estimating relationships between variables, rates, or means might be safely ignores if the sample design is capable of generating sample of equal probability. [41] Called these designs epsem designs and stated that at near final or the final or stage of the design, epsem can be designed even with complex multi-stage samples. Even with the initially epsem design, unequal weights can be created by the adjustments for non-response.

\section{Results \& discussion}

\subsection{Characteristics of woman respondents}

First, descriptive analysis using frequency tabulation was conducted. The Lists in Table1 indicate that 32,599 women (age 15-49 years) identified in the selected households, 26,923 were successfully interviewed, yielding a response rate of 82.6 percent. It is important to note that while the average response rate for women's were over 90 percent in 11 states, between 80 and 90 percent in five states, between 70 and 80 per cent in two states, between 60 and 70 percent in three states and between 50 and 60 percent in four states, being highest in Gezira at 98.6 per cent and the lowest in Western Bahr El Ghazal at 55.4 per cent. , as indicated in Table1, the response rate for women was low. The response rate for women's questionnaire was less than 60 per cent in four states in Southern Sudan. 
Table 1: Number of Women Response Rates

\begin{tabular}{|c|c|c|c|c|c|c|c|c|}
\hline state & Completed & $\begin{array}{l}\text { Not at } \\
\text { home }\end{array}$ & Refused & $\begin{array}{l}\text { Partly } \\
\text { completed }\end{array}$ & Incapacitated & Other & Total & Response rate $\%$ \\
\hline Northern & 1290 & 54 & 0 & 0 & 16 & 20 & 1380 & $93.5 \%$ \\
\hline River Nile & 1408 & 54 & 2 & 0 & 7 & 1 & 1472 & $95.7 \%$ \\
\hline Red Sea & 1139 & 17 & 3 & 1 & 3 & 12 & 1175 & $96.9 \%$ \\
\hline Kassala & 1200 & 14 & 0 & 0 & 7 & 20 & 1241 & $96.7 \%$ \\
\hline Gadarif & 1207 & 44 & 5 & 0 & 8 & 26 & 1290 & $93.6 \%$ \\
\hline Khartoum & 1324 & 183 & 13 & 1 & 1 & 34 & 1556 & $85.1 \%$ \\
\hline Gezira & 1533 & 13 & 0 & 0 & 4 & 5 & 1555 & $98.6 \%$ \\
\hline Sinnar & 1347 & 21 & 0 & 0 & 1 & 17 & 1386 & $97.2 \%$ \\
\hline Blue Nile & 1220 & 101 & 5 & 0 & 5 & 6 & 1337 & $91.2 \%$ \\
\hline White Nile & 1500 & 23 & 1 & 0 & 6 & 4 & 1534 & $97.8 \%$ \\
\hline North kordofan & 1258 & 55 & 3 & 0 & 8 & 14 & 1338 & $94.0 \%$ \\
\hline South kordofan & 905 & 140 & 3 & 0 & 0 & 12 & 1060 & $85.4 \%$ \\
\hline North Darfur & 1055 & 104 & 4 & 0 & 2 & 32 & 1197 & $88.1 \%$ \\
\hline West Darfur & 773 & 97 & 6 & 1 & 1 & 24 & 902 & $85.7 \%$ \\
\hline South Darfur & 1027 & 39 & 1 & 0 & 5 & 12 & 1084 & $94.7 \%$ \\
\hline Jongolei & 887 & 197 & 33 & 0 & 0 & 339 & 1456 & $60.9 \%$ \\
\hline Upper Nile & 612 & 223 & 17 & 0 & 1 & 101 & 954 & $64.2 \%$ \\
\hline Unity & 906 & 274 & 38 & 2 & 1 & 92 & 1313 & $69.0 \%$ \\
\hline Warab & 1046 & 172 & 24 & 0 & 1 & 114 & 1357 & $77.1 \%$ \\
\hline $\begin{array}{l}\text { North Bahr } \\
\text { Al_Gazal }\end{array}$ & 837 & 308 & 31 & 3 & 0 & 319 & 1498 & $55.9 \%$ \\
\hline $\begin{array}{l}\text { Wēst Bahr } \\
\text { Al_Gazal }\end{array}$ & 717 & 287 & 18 & 1 & 0 & 272 & 1295 & $55.4 \%$ \\
\hline Lakes & 899 & 352 & 63 & 0 & 1 & 170 & 1485 & $60.5 \%$ \\
\hline West Equatoria & 825 & 303 & 13 & 0 & 1 & 53 & 1195 & $69.0 \%$ \\
\hline $\begin{array}{l}\text { Central } \\
\text { Equatoria }\end{array}$ & 1067 & 242 & 43 & 17 & 0 & 47 & 1416 & $75.4 \%$ \\
\hline East Equatoria & 941 & 105 & 11 & 0 & 0 & 66 & 1123 & $83.8 \%$ \\
\hline Total & 26923 & 3422 & 337 & 26 & 79 & 1812 & 32599 & $82.6 \%$ \\
\hline
\end{tabular}

Table2 display the characteristics of female respondents 15-49 years of age. The table includes information on the distribution of women according to age, marital status, motherhood status, education and wealth index quintiles In addition to providing useful information on the background characteristics of women, the table is also show the numbers of observations in each background category. These categories are used in the subsequent tabulations of this work.

Table 2 Women in the age group 25-29 years constituted the largest proportion $(21.1 \%)$ of the total number of women followed by women in the age group 20-24 years (18.7 per cent), women in the age group 15-19 years (17.7 per cent), women in the age group 30-34 years (14.9 per cent), and women in the age group 35-39 years (14.1\%). About $8 \%$ of the women were in the age group 40-44 years while the lowest proportion of women was in the age group 45-49 years ( 5.5 per cent). About 65.5 percent were currently married/in union and 28.6 per cent were formerly married/in union while never married/in union women constituted 5.9 percent. Women with no formal education made up 49.8 percent of the total while 41.2 per cent had primary education and 8.9 percent had secondary or higher education. The wealth index quintiles show that about 17.7 percent of women belong to the poorest households while women from the richest households constitute about 23.5 percent. 
Table 2: Women's Characteristics

\begin{tabular}{|c|c|c|c|c|}
\hline & \multicolumn{2}{|c|}{ Number of woman } \\
\hline & & & weighted & unweighted \\
\hline \multirow{14}{*}{ Age } & \multirow{2}{*}{$15-19$} & Count & 1529508 & 4677 \\
\hline & & $\%$ of Total & $17.7 \%$ & $17.4 \%$ \\
\hline & \multirow{2}{*}{$20-24$} & Count & 1611527 & 5005 \\
\hline & & $\%$ of Total & $18.6 \%$ & $18.6 \%$ \\
\hline & \multirow{2}{*}{$25-29$} & Count & 1835955 & 5847 \\
\hline & & $\%$ of Total & $21.2 \%$ & $21.7 \%$ \\
\hline & \multirow{2}{*}{$30-34$} & Count & 1291155 & 4037 \\
\hline & & $\%$ of Total & $14.9 \%$ & $15.0 \%$ \\
\hline & \multirow{2}{*}{$35-39$} & Count & 1217325 & 3778 \\
\hline & & $\%$ of Total & $14.1 \%$ & $14.0 \%$ \\
\hline & \multirow{2}{*}{$40-44$} & Count & 696905 & 2099 \\
\hline & & $\%$ of Total & $8.0 \%$ & $7.8 \%$ \\
\hline & \multirow{2}{*}{$45-49$} & Count & 475590 & 1479 \\
\hline & & $\%$ of Total & $5.5 \%$ & $5.5 \%$ \\
\hline \multirow{2}{*}{\multicolumn{2}{|c|}{ Total }} & Count & 8657965 & 8657965 \\
\hline & & $\%$ of Total & $100.0 \%$ & $100.0 \%$ \\
\hline \multirow{6}{*}{ Marital/Union status } & \multirow{2}{*}{ Currently married/in union } & Count & 5435614 & 17216 \\
\hline & & $\%$ of Total & $66.1 \%$ & $67.8 \%$ \\
\hline & \multirow{2}{*}{ Formerly married/in union } & Count & 2292572 & 6688 \\
\hline & & $\%$ of Total & $27.9 \%$ & $26.3 \%$ \\
\hline & \multirow{2}{*}{ Never married/in union } & Count & 495020 & 1487 \\
\hline & & $\%$ of Total & $6.0 \%$ & $5.9 \%$ \\
\hline \multirow{2}{*}{\multicolumn{2}{|c|}{ Total }} & Count & 8223206 & 25391 \\
\hline & & $\%$ of Total & $100.0 \%$ & $100.0 \%$ \\
\hline \multirow{4}{*}{$\begin{array}{l}\text { Motherhood status } \\
\text { Ever given birth }\end{array}$} & \multirow{2}{*}{ Yes } & Count & 5615186 & 17882 \\
\hline & & $\%$ of Total & $64.9 \%$ & $66.4 \%$ \\
\hline & \multirow{2}{*}{ No } & Count & 3041795 & 9034 \\
\hline & & $\%$ of Total & $33.6 \%$ & $35.1 \%$ \\
\hline \multirow{2}{*}{\multicolumn{2}{|c|}{ Total }} & Count & 8656981 & 26916 \\
\hline & & $\%$ of Total & $100.0 \%$ & $100.0 \%$ \\
\hline & & Count & 4353377 & 14716 \\
\hline & None & $\%$ of Total & $50.3 \%$ & $54.7 \%$ \\
\hline & & Count & 3508224 & 10383 \\
\hline Education & Primary & $\%$ of Total & $40.5 \%$ & $38.6 \%$ \\
\hline Eaucation & & Count & 784808 & 1776 \\
\hline & Secondary + & $\%$ of Total & $9.1 \%$ & $6.6 \%$ \\
\hline & & Count & 11981 & 48 \\
\hline & Missing/DK & $\%$ of Total & $.1 \%$ & $.2 \%$ \\
\hline & & Count & 8658390 & 26923 \\
\hline Total & & $\%$ of Total & $100.0 \%$ & $100.0 \%$ \\
\hline & & Count & 1611387 & 5067 \\
\hline & Poorest & $\%$ of Total & $21.4 \%$ & $21.1 \%$ \\
\hline & Second & Count & 1497565 & 4720 \\
\hline & Second & $\%$ of Total & $19.9 \%$ & $19.6 \%$ \\
\hline Wealth index guintiles & Middle & Count & 1357048 & 4329 \\
\hline wealth index quintiles & Mnidale & $\%$ of Total & $18.0 \%$ & $18.0 \%$ \\
\hline & Fourth & Count & 1051533 & 3342 \\
\hline & Fourth & $\%$ of Total & $14.0 \%$ & $13.9 \%$ \\
\hline & & Count & 700768 & 2282 \\
\hline & Richest & $\%$ of Total & $9.3 \%$ & $9.5 \%$ \\
\hline Total & & Count & 6218301 & 19740 \\
\hline I otal & & $\%$ of Total & $82.6 \%$ & $82.1 \%$ \\
\hline
\end{tabular}




\subsection{Describing the pattern of missing data}

Table 3: Univariate Statistics Pattern of Missing Data

\begin{tabular}{|l|l|l|l|l|l|l|l|}
\hline & $\mathrm{N}$ & Mean & Std. Deviation & Missing & \multicolumn{2}{l|}{ No. of Extremes } \\
\cline { 5 - 9 } & & & & Count & Percent & Low & High \\
\hline $\begin{array}{l}\text { Marital/Union } \\
\text { status }\end{array}$ & 8210555 & 1.40 & .600 & 2182830 & 21.0 & 0 & 1487 \\
\hline $\begin{array}{l}\text { Wealth index } \\
\text { quintiles }\end{array}$ & 7513617 & 2.66 & 1.333 & 2879768 & 27.7 & 0 & 0 \\
\hline Education & 8645015 & 1.60 & .707 & 1748370 & 16.8 & 0 & 48 \\
\hline Ever given birth & 8643611 & 1.35 & .477 & 1749774 & 16.8 & 0 & 0 \\
\hline Age of Woman & 8645015 & & & 1748370 & 16.8 & & \\
\hline
\end{tabular}

a. Number of cases outside the range (Mean $-2 * \mathrm{SD}$, Mean $+2 * \mathrm{SD})$

Table3 Indicate that withl5 (Wealth index quintile) has the greatest number of cases with missing values (27.7\%), while age (Age of woman), melevel (level of education) and $\mathrm{cm} 1$ (ever given birth) has the least (16.8\%). Marital/Union status has the greatest number of extreme values.

Table 4: Separate Variance T Testsa Pattern of Missing Data

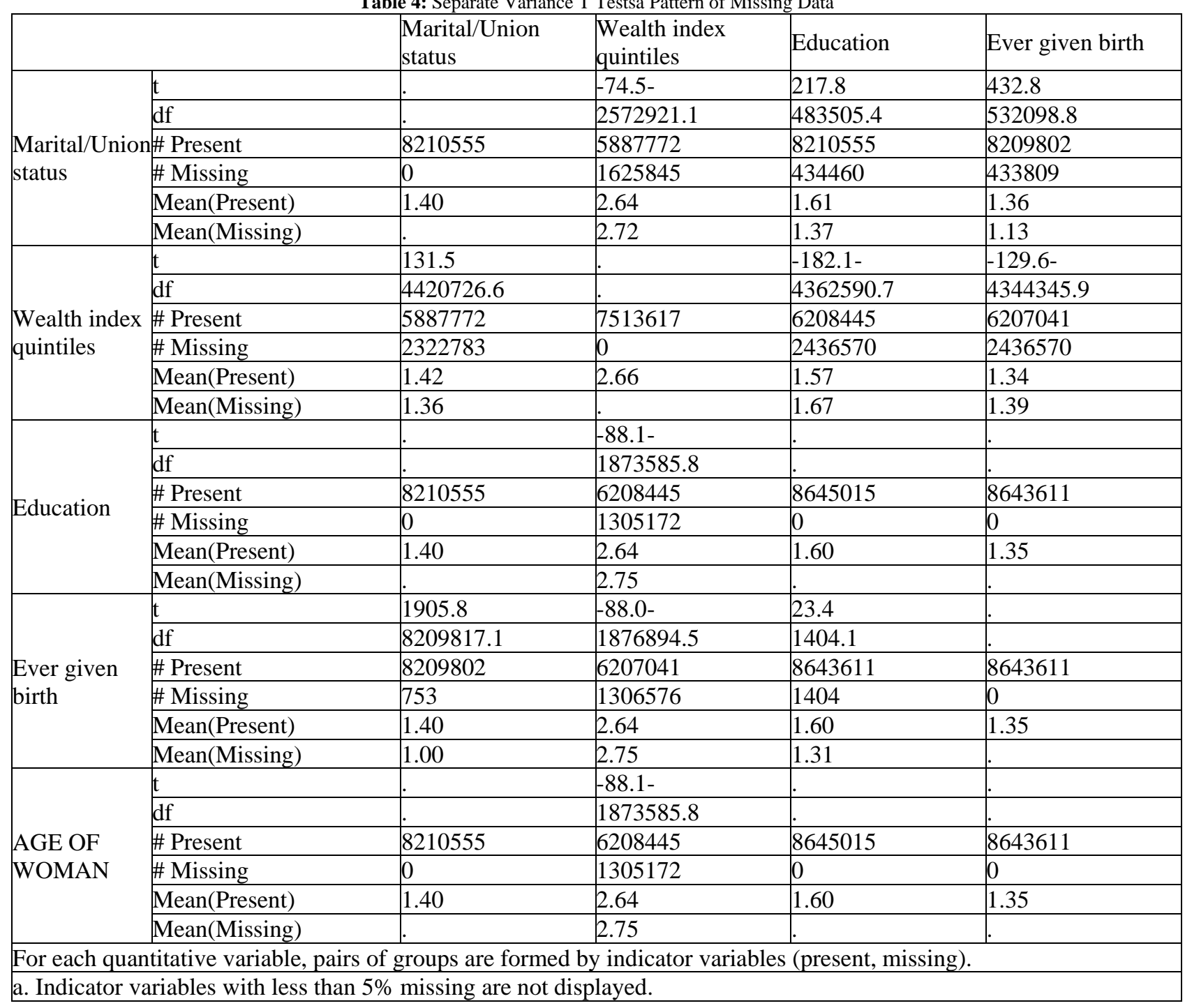

Table4 show that when wealth is missing, the mean education is 1.57 , compared to 1.67 when wealth is no missing. In fact, the missingness of wealth seems to affect the means of several of the quantitative (scale) variables. This is one indication that the data may not be missing completely at random. 
Table 8: Mstatus (Marital Status) Pattern of Missing Data

\begin{tabular}{|c|c|c|c|c|c|c|c|}
\hline & & & & Currently & Formerly & Never & Missing \\
\hline & & & Total & $\begin{array}{l}\text { married/in } \\
\text { union }\end{array}$ & $\begin{array}{l}\text { married/in } \\
\text { union }\end{array}$ & $\begin{array}{l}\text { married/in } \\
\text { union }\end{array}$ & SysMis \\
\hline & Procant & Count & 8645015 & 5427278 & 2289044 & 494233 & 434460 \\
\hline WM9 & Present & Percent & 83.2 & 100.0 & 100.0 & 100.0 & 19.9 \\
\hline & Missing & $\%$ SysMis & 16.8 & .0 & .0 & .0 & 80.1 \\
\hline & & Count & 8643611 & 5426525 & 2289044 & 494233 & 433809 \\
\hline CM1 & Present & Percent & 83.2 & 100.0 & 100.0 & 100.0 & 19.9 \\
\hline & Missing & $\%$ SysMis & 16.8 & .0 & .0 & .0 & 80.1 \\
\hline & & Count & 8645015 & 5427278 & 2289044 & 494233 & 434460 \\
\hline melevel & Present & Percent & 83.2 & 100.0 & 100.0 & 100.0 & 19.9 \\
\hline & Missing & $\%$ SysMis & 16.8 & .0 & .0 & .0 & 80.1 \\
\hline & & Count & 7513617 & 3804983 & 1715323 & 367466 & 1625845 \\
\hline wlthind5 & Present & Percent & 72.3 & 70.1 & 74.9 & 74.4 & 74.5 \\
\hline & Missing & $\%$ SysMis & 27.7 & 29.9 & 25.1 & 25.6 & 25.5 \\
\hline
\end{tabular}

Looking at the Table 8 for melevel (Marital status), the number of missing values in the indicator variables does not appear to vary much between melevel (marital status) categories. Unmarried people reported wm9 (Age of woman) $100.0 \%$ of the time, and married people reported the same variable $100.0 \%$ of the time. The difference is none.

Table 9: Melevel (Education) Pattern of Missing Data

\begin{tabular}{|c|c|c|c|c|c|c|c|c|}
\hline & & & Total & None & Primary & Secondary + & Missing/DK & $\begin{array}{l}\text { Missing } \\
\text { SysMis }\end{array}$ \\
\hline \multirow{3}{*}{ WM9 } & \multirow{2}{*}{ Present } & Count & 8645015 & 4346614 & 3502454 & 783983 & 11964 & 0 \\
\hline & & Percent & 83.2 & 100.0 & 100.0 & 100.0 & 100.0 & .0 \\
\hline & Missing & $\%$ SysMis & 16.8 & .0 & .0 & .0 & .0 & 100.0 \\
\hline \multirow{3}{*}{ CM1 } & \multirow{2}{*}{ Present } & Count & 8643611 & 4345644 & 3502020 & 783983 & 11964 & 0 \\
\hline & & Percent & 83.2 & 100.0 & 100.0 & 100.0 & 100.0 & .0 \\
\hline & Missing & $\%$ SysMis & 16.8 & .0 & .0 & .0 & .0 & 100.0 \\
\hline \multirow{3}{*}{ mstatus } & \multirow{2}{*}{ Present } & Count & 8210555 & 4048820 & 3384147 & 766910 & 10678 & 0 \\
\hline & & Percent & 79.0 & 93.1 & 96.6 & 97.8 & 89.3 & .0 \\
\hline & Missing & $\%$ SysMis & 21.0 & 6.9 & 3.4 & 2.2 & 10.7 & 100.0 \\
\hline \multirow{3}{*}{ wlthind5 } & \multirow{2}{*}{ Present } & Count & 7513617 & 3248990 & 2432898 & 517820 & 8737 & 1305172 \\
\hline & & Percent & 72.3 & 74.7 & 69.5 & 66.0 & 73.0 & 74.7 \\
\hline & Missing & $\%$ SysMis & 27.7 & 25.3 & 30.5 & 34.0 & 27.0 & 25.3 \\
\hline
\end{tabular}

Now consider the cross tabulation Table 9 for melevel (Level of education). If a respondent has at least some secondary+ education, a response for marital status is more to be missing. At least $93.1 \%$ of the respondents with none education reported marital status. On the other hand, only $97.8 \%$ of those with a secondary + reported marital status. The number is even lower for those with none education,

Table 10: Wlthind5 (Wealth) Pattern of Missing Data

\begin{tabular}{|c|c|c|c|c|c|c|c|c|c|}
\hline & & & Total & Poorest & Second & Middle & Fourth & Richest & $\begin{array}{l}\text { Missing } \\
\text { SysMis } \\
\end{array}$ \\
\hline \multirow{3}{*}{ WM9 } & \multirow{2}{*}{ Present } & Count & 8645015 & 1608916 & 1495252 & 699573 & 1049835 & 699573 & 2436570 \\
\hline & & Percent & 83.2 & 84.4 & 82.4 & 79.2 & 82.6 & 79.2 & 84.6 \\
\hline & Missing & $\%$ SysMis & 16.8 & 15.6 & 17.6 & 20.8 & 17.4 & 20.8 & 15.4 \\
\hline \multirow{3}{*}{ CM1 } & \multirow{2}{*}{ Present } & Count & 8643611 & 1608916 & 1494420 & 699573 & 1049618 & 699573 & 2436570 \\
\hline & & Percent & 83.2 & 84.4 & 82.4 & 79.2 & 82.6 & 79.2 & 84.6 \\
\hline & Missing & $\%$ SysMis & 16.8 & 15.6 & 17.6 & 20.8 & 17.4 & 20.8 & 15.4 \\
\hline \multirow{3}{*}{ mstatus } & \multirow{2}{*}{ Present } & Count & 8210555 & 1529072 & 1412702 & 664627 & 998739 & 664627 & 2322783 \\
\hline & & Percent & 79.0 & 80.2 & 77.9 & 75.3 & 78.6 & 75.3 & 80.7 \\
\hline & Missing & $\%$ SysMis & 21.0 & 19.8 & 22.1 & 24.7 & 21.4 & 24.7 & 19.3 \\
\hline \multirow{3}{*}{ melevel } & \multirow{2}{*}{ Present } & Count & 8645015 & 1608916 & 1495252 & 699573 & 1049835 & 699573 & 2436570 \\
\hline & & Percent & 83.2 & 84.4 & 82.4 & 79.2 & 82.6 & 79.2 & 84.6 \\
\hline & Missing & $\%$ SysMis & 16.8 & 15.6 & 17.6 & 20.8 & 17.4 & 20.8 & 15.4 \\
\hline
\end{tabular}


Now consider the cross tabulation Table 10 for wlthind5 (wealth). If a respondent has at least some wealth, a response for melevel (education level) is more to be missing. At least $84.4 \%$ of the respondents with poorest wealth reported melevel (education). On the other hand, only $82.6 \%$ of those with Middle reported melevel (education level). The number is even lowering for those with richest.

Table 11: EM Estimated Statistics

EM Means $^{\mathrm{a}}$

WM9(age of woman)

28.20

a. Little's MCAR test: Chi-Square $=.001, \mathrm{DF}=0$, Sig. $=$.

EM Covariances $^{\mathrm{a}}$

\begin{tabular}{|l|l|}
\hline & WM9 \\
\hline WM9 & 73.123 \\
\hline
\end{tabular}

a. Little's MCAR test: Chi-Square $=.001, \mathrm{DF}=0$, Sig. $=$.

EM Correlations $^{\mathrm{a}}$

\begin{tabular}{|l|l}
\hline & WM9 \\
\hline WM9 & 1 \\
\hline a. Little's MCAR test: Chi-Square $=.001$, DF $=0$, Sig. $=$.
\end{tabular}

Table 11 describe that the null hypothesis for Little's MCAR test is that the data are missing completely at random (MCAR). Because the significance value is less than 0.05 in our work, we can conclude that the data are not missing completely at random. This confirms the conclusion we drew from the descriptive statistics and tabulated patterns.

\subsection{Using multiple imputations to complete and analyze a dataset}

\section{Overall Summary of Missing Values}

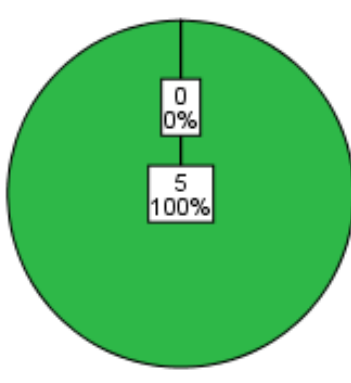

Variables

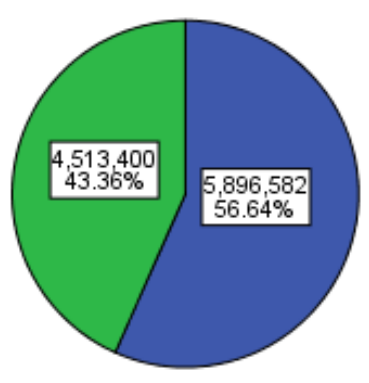

Cases

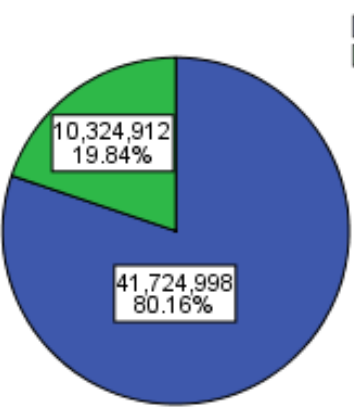

Values

Fig. 1: Shows That:

- The Variables chart shows that each of the 5 analysis variables has at least one missing value on a case.

- The Cases chart shows that 4,513,400 of the 10,000,000 cases have at least one missing value on a variable.

- The Values chart shows that $10,324,912$ of the $50,000,000$ values (cases $\times$ variables) are missing.

- There are $5896582(56.64 \%)$ complete cases and $80.16 \%$ complete values.

\subsection{Imputation models}

Table 13: Imputation Specifications

Imputation Method

Number of Imputations

Model for Scale Variables

Interactions Included in Models

Maximum Percentage of Missing Values

Maximum Number of Parameters in Imputation Model

Replication Weight Variable
Automatic

5

Linear Regression

(none)

$100.0 \%$

100

wmweight 
Table 14: Imputation Results

Imputation Method

Fully Conditional Specification

Fully Conditional Specification Method Iterations

10

\begin{tabular}{|l|l|l|}
\hline \multirow{3}{*}{ Dependent Variables } & $\begin{array}{l}\text { Imputed } \\
\text { Not Imputed(Too Many Missing } \\
\text { Values) }\end{array}$ & \\
\cline { 2 - 3 } & Not Imputed(No Missing Values) & \\
\hline Imputation Sequence & WM9,melevel,CM1,mstatus,wlthind5 \\
\hline
\end{tabular}

Table 15: Imputation Models

\begin{tabular}{|l|l|l|l|l|}
\hline & Model & Missing Values & Imputed Values \\
\cline { 2 - 5 } & Type & Effects & 1307138 & 6535690 \\
\hline Age of woman & Linear Regression & melevel,CM1,mstatus,wlthind5 & 1307138 & 6535690 \\
\hline Education & Logistic Regression & CM1,mstatus,wlthind5,WM9 & 6542745 \\
\hline Ever given birth & Logistic Regression & melevel,mstatus,wlthind5,WM9 & 1308549 & 8712390 \\
\hline Marital/Union status & Logistic Regression & melevel,CM1,wlthind5,WM9 & 1742478 & 12201545 \\
\hline Wealth index quintiles & Logistic Regression & melevel,CM1,mstatus,WM9 & 2440309 & \\
\hline
\end{tabular}

Table 16: WM9 (Age of Woman) Imputed Values

\begin{tabular}{|l|l|l|l|l|l|l|}
\hline Data & Imputation & $\mathrm{N}$ & Mean & Std. Deviation & Minimum & Maximum \\
\hline Original Data & & 8658984 & 28.37 & 8.636 & 15.00 & 49.00 \\
\hline \multirow{5}{*}{ Imputed Values } & 1 & 1307138 & 28.76 & 8.528 & $-4.47-$ & 56.87 \\
\cline { 2 - 7 } & 2 & 1307138 & 28.39 & 8.702 & $-7.61-$ & 57.23 \\
\cline { 2 - 7 } & 3 & 1307138 & 28.59 & 8.441 & $-.81-$ & 57.55 \\
\cline { 2 - 7 } & 4 & 1307138 & 28.90 & 8.564 & $-.41-$ & 57.32 \\
\hline \multirow{5}{*}{$\begin{array}{l}\text { Complete Data After } \\
\text { Imputation }\end{array}$} & 5 & 1307138 & 28.94 & 8.599 & $-3.80-$ & 57.55 \\
\cline { 2 - 7 } & 1 & 9966122 & 28.42 & 8.623 & $-4.47-$ & 56.87 \\
\cline { 2 - 7 } & 3 & 9966122 & 28.37 & 8.645 & $-7.61-$ & 57.23 \\
\cline { 2 - 7 } & 4 & 9966122 & 28.40 & 8.611 & $-.41-$ & 57.55 \\
\cline { 2 - 7 } & 5 & 9966122 & 28.44 & 8.628 & $-3.80-$ & 57.52 \\
\hline
\end{tabular}

The descriptive statistics Table 16 for wm9 (Age of woman) shows means and standard deviations in each set of imputed values roughly equal to those in the original data; however, an immediate problem presents itself when you look at the minimum and see that negative values for age have been imputed. We will need to run a custom model with constraints on certain variables. However, age shows other potential problems. The mean values for each imputation are considerably higher than for the original data, and the maximum values for each imputation are considerably lower than for the original data. The distribution of age tends to be highly right-skew, so this could be the source of the problem.

\subsection{Custom imputation model}

wm9(age of woman's) is highly right-skew, and further analysis will likely use the logarithm of age, so it seems sensible to impute the log-age directly see Table 21 .

\begin{tabular}{|c|c|c|c|c|c|c|}
\hline Data & Imputation & $\mathrm{N}$ & Mean & Std. Deviation & Minimum & Maximum \\
\hline Original Data & & 8658984 & 3.2982 & .30925 & 2.7081 & 3.8918 \\
\hline \multirow{5}{*}{ Imputed Values } & 1 & 1307138 & 3.3007 & .30916 & 2.2083 & 4.3542 \\
\hline & 2 & 1307138 & 3.3056 & .31072 & 2.1610 & 4.3468 \\
\hline & 3 & 1307138 & 3.3097 & .30939 & 2.2814 & 4.3984 \\
\hline & 4 & 1307138 & 3.2919 & .30790 & 2.2108 & 4.3906 \\
\hline & 5 & 1307138 & 3.2924 & 31190 & 2.2033 & 4.4032 \\
\hline \multirow{5}{*}{$\begin{array}{l}\text { Complete Data After } \\
\text { Imputation }\end{array}$} & 1 & 9966122 & 3.2986 & .30924 & 2.2083 & 4.3542 \\
\hline & 2 & 9966122 & 3.2992 & .30945 & 2.1610 & 4.3468 \\
\hline & 3 & 9966122 & 3.2997 & .30929 & 2.2814 & 4.3984 \\
\hline & 4 & 9966122 & 3.2974 & .30908 & 2.2108 & 4.3906 \\
\hline & 5 & 9966122 & 3.2975 & .30961 & 2.2033 & 4.4032 \\
\hline
\end{tabular}

The descriptive statistics in Table 21 for logage (age of woman) under the custom imputation model with constraints shows that the problem of negative imputed values for tenure has been solved. 


\subsection{Nominal regression}

Table 22: Case Processing Summary

\begin{tabular}{|c|c|c|c|}
\hline & & $\mathrm{N}$ & Marginal Percentage \\
\hline \multirow{6}{*}{ Result of women 's interview } & Completed & 153204 & $87.7 \%$ \\
\hline & Not at home & 12880 & $7.4 \%$ \\
\hline & Refused & 1230 & $.7 \%$ \\
\hline & Partly completed & 85 & $.0 \%$ \\
\hline & Incapacitated & 295 & $.2 \%$ \\
\hline & Other & 7040 & $4.0 \%$ \\
\hline \multirow{2}{*}{ Ever given birth } & Yes & 115766 & $66.3 \%$ \\
\hline & No & 58968 & $33.7 \%$ \\
\hline \multirow{3}{*}{ Marital/Union status } & Currently married/in union & 117017 & $67.0 \%$ \\
\hline & Formerly married/in union & 47510 & $27.2 \%$ \\
\hline & Never married/in union & 10207 & $5.8 \%$ \\
\hline \multirow{4}{*}{ Education } & None & 93235 & $53.4 \%$ \\
\hline & Primary & 66909 & $38.3 \%$ \\
\hline & Secondary + & 11895 & $6.8 \%$ \\
\hline & Missing/DK & 2695 & $1.5 \%$ \\
\hline \multirow{5}{*}{ Wealth index quintiles } & Poorest & 44191 & $25.3 \%$ \\
\hline & Second & 41833 & $23.9 \%$ \\
\hline & Middle & 38289 & $21.9 \%$ \\
\hline & Fourth & 29543 & $16.9 \%$ \\
\hline & Richest & 20878 & $11.9 \%$ \\
\hline \multicolumn{2}{|l|}{ Valid } & 174734 & $100.0 \%$ \\
\hline \multicolumn{2}{|l|}{ Missing } & 20860 & \\
\hline \multicolumn{2}{|l|}{ Total } & 195594 & \\
\hline \multicolumn{2}{|l|}{ Subpopulation } & $24001^{\mathrm{a}}$ & \\
\hline
\end{tabular}

Table 23: Model Fitting Information

\begin{tabular}{|l|l|l|l|l|}
\hline \multirow{2}{*}{ Model } & Model Fitting Criteria & Likelihood Ratio Tests & \\
\cline { 2 - 5 } & -2 Log Likelihood & Chi-Square & df & \\
\hline Intercept Only & 169938.358 & & & \\
\hline Final & 160575.209 & 9363.149 & 55 & .000 \\
\hline
\end{tabular}

Table 24: Pseudo R-Square

\begin{tabular}{lr}
\hline Cox and Snell & .052 \\
\hline Nagelkerke & .084 \\
McFadden & .055 \\
\hline
\end{tabular}

Table 25: Likelihood Ratio Tests

\begin{tabular}{|c|c|c|c|c|}
\hline \multirow[b]{2}{*}{ Effect } & \multicolumn{4}{|c|}{ Model Fitting Criteria Likelihood Ratio Tests } \\
\hline & $\begin{array}{l}\text {-2 Log Likelihood of } \\
\text { Reduced Model }\end{array}$ & Chi-Square & df & Sig. \\
\hline Intercept & $160575.209^{\mathrm{a}}$ & .000 & 0 & . \\
\hline logage & 160576.806 & 1.597 & 5 & .902 \\
\hline melevel & 169534.249 & 8959.040 & 15 & .000 \\
\hline CM1 & 160645.603 & 70.394 & 5 & .000 \\
\hline mstatus & 160618.077 & 42.868 & 10 & .000 \\
\hline wlthind5 & 160840.481 & 265.272 & 20 & .000 \\
\hline
\end{tabular}

The chi-square statistic is the difference in -2 log-likelihoods between the final model and a reduced model. The reduced model is formed by omitting an effect from the final model. The null hypothesis is that all parameters of that effect are 0 .

a. This reduced model is equivalent to the final mode 1 because omitting the effect does not increase the degrees of freedom.

Table 26: Model Fitting Information

\begin{tabular}{lllll}
\hline \multirow{2}{*}{ Model } & \multicolumn{2}{l}{ Model Fitting CriteriaLikelihood Ratio Tests } & \multirow{2}{*}{ Sig. } \\
& -2 Log Likelihood & Chi-Square & df & \\
Intercept Only & 169938.358 & & & .000 \\
Final & 160575.209 & 9363.149 & 55 & \\
\hline
\end{tabular}


Table 28: Pseudo R-Square

\begin{tabular}{lc}
\hline Cox and Snell & .052 \\
\hline Nagelkerke & .084 \\
McFadden & .055 \\
\hline
\end{tabular}

Table 27: Likelihood Ratio Tests

\begin{tabular}{|c|c|c|c|c|}
\hline \multirow{2}{*}{ Effect } & \multirow{2}{*}{$\begin{array}{l}\text { Model Fitting Criteria } \\
-2 \text { Log Likelihood of Reduced Model } \\
\end{array}$} & \multicolumn{3}{|c|}{ Likelihood Ratio Tests } \\
\hline & & Chi-Square & df & Sig. \\
\hline Intercept & $160575.209^{\mathrm{a}}$ & .000 & 0 & . \\
\hline logage & 160576.806 & 1.597 & 5 & .902 \\
\hline melevel & 169534.249 & 8959.040 & 15 & .000 \\
\hline CM1 & 160645.603 & 70.394 & 5 & .000 \\
\hline mstatus & 160618.077 & 42.868 & 10 & .000 \\
\hline wlthind5 & 160840.481 & 265.272 & 20 & .000 \\
\hline
\end{tabular}

The chi-square statistic is the difference in -2 log-likelihoods between the final model and a reduced model. The reduced model is formed by omitting an effect from the final model. The null hypothesis is that all parameters of that effect are 0 .

a. This reduced model is equivalent to the final model because omitting the effect does not increase the degrees of freedom.

\subsection{Two-step cluster analysis}

\section{Model Summary}

\begin{tabular}{|l|l|}
\hline Algorithm & TwoStep \\
\hline Inputs & 5 \\
\hline Clusters & 2 \\
\hline
\end{tabular}

\section{Cluster Quality}

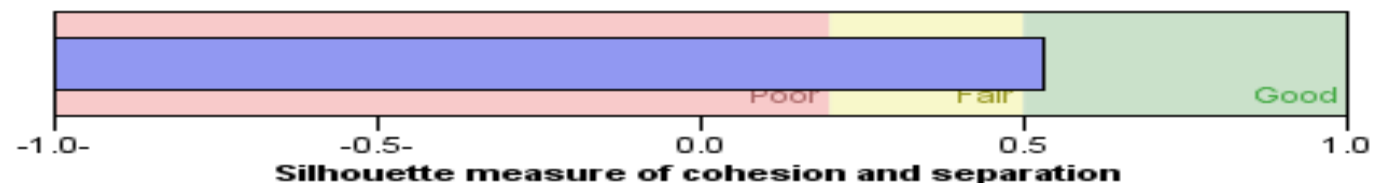

Fig. 1: Model Summary

- $\quad$ The model summary table in Fig.2 indicates that tow clusters were found based on the seven input features (fields) selected.

The cluster quality chart in Fig. 2, Fig. 5 and Fig. 10 indicates that the model summary quality is "Good" while quality chart in Fig. 6, Fig. 8 and Fig. 12 indicates that the model summary quality is "Fair". 


\section{Clusters}

Input (Predictor) Importance

$\square 1.0 \square 0.8 \square 0.6 \square 0.4 \square 0.2 \square 0.0$

\begin{tabular}{|c|c|c|}
\hline Cluster & 2 & 1 \\
\hline \multicolumn{3}{|l|}{ Label } \\
\hline \multicolumn{3}{|l|}{ Description } \\
\hline Size & $\begin{array}{l}66.1 \% \\
(7814)\end{array}$ & $\begin{array}{l}33.9 \% \\
(4004)\end{array}$ \\
\hline \multirow[t]{5}{*}{ Inpurts } & $\begin{array}{l}\text { Education } \\
\text { None }(100.0 \%)\end{array}$ & $\begin{array}{c}\text { Education } \\
\text { Primary }(66.9 \%)\end{array}$ \\
\hline & $\begin{array}{l}\text { Ever given birth } \\
\text { Yes }(100.0 \%)\end{array}$ & $\begin{array}{c}\text { Ever given birth } \\
\text { No }(100.0 \%)\end{array}$ \\
\hline & $\underset{3.40}{\operatorname{logage}}$ & $\begin{array}{l}\operatorname{logage} \\
3.04\end{array}$ \\
\hline & $\begin{array}{c}\text { Marital/Union status } \\
\text { Currently married/in } \\
\text { union }(66.0 \%)\end{array}$ & $\begin{array}{c}\text { Marital/Union status } \\
\text { Currently married/in } \\
\text { union ( } 100.0 \%)\end{array}$ \\
\hline & $\begin{array}{c}\text { Wealth index } \\
\text { quintiles } \\
\text { Poorest }(25.6 \%)\end{array}$ & $\begin{array}{c}\text { Wealth index } \\
\text { quintiles } \\
\text { Poorest }(31.7 \%)\end{array}$ \\
\hline
\end{tabular}

Fig. 2: Custer

The Cluster Sizes view in Fig. 3 shows the frequency of each cluster. Hovering over a slice in the pie chart reveals the number of records assigned to the cluster. $33.9 \%$ (4004) of the records were assigned to the first cluster and $66.1 \%$ (7814) to the second.

\section{Model Summary}

\begin{tabular}{|l|l|}
\hline Algorithm & TwoStep \\
\hline Inputs & 5 \\
\hline Clusters & 9 \\
\hline
\end{tabular}

\section{Cluster Quality}

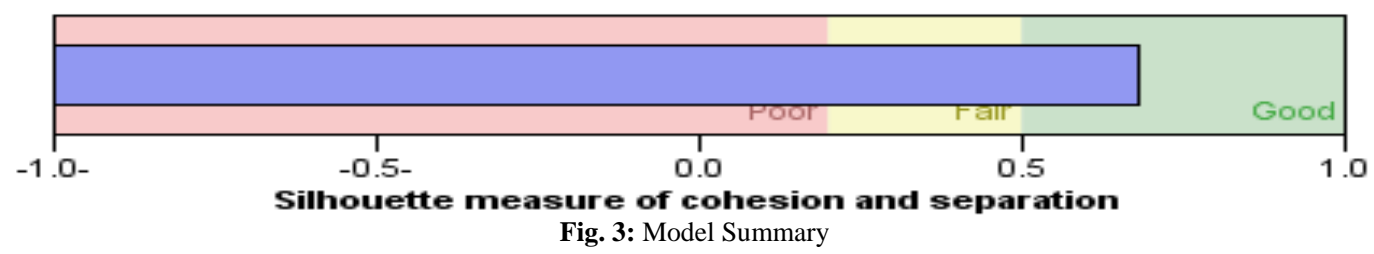




\section{Model Summary}

\begin{tabular}{|l|l|}
\hline Algorithm & TwoStep \\
\hline Inputs & 5 \\
\hline Clusters & 4 \\
\hline
\end{tabular}

\section{Cluster Quality}

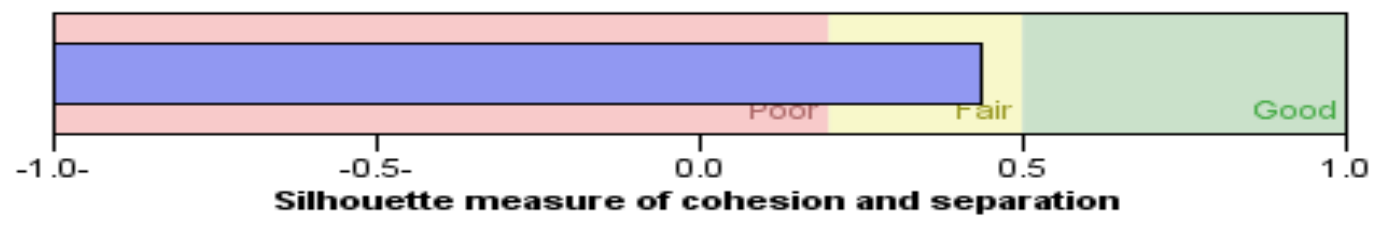

Fig. 4: Model Summary

\section{Clusters}

Input (Predictor) Importance

$\square 1.0 \square 0.8 \square 0.6 \square 0.4 \square 0.2 \square 0.0$

\begin{tabular}{|c|c|c|c|}
\hline Cluster & $-1.79769 e+308$ & 2 & 1 \\
\hline \multicolumn{4}{|l|}{ Label } \\
\hline \multicolumn{4}{|l|}{ Description } \\
\hline Size & $\left|\begin{array}{l}36.6 \% \\
(8803)\end{array}\right|$ & $\begin{array}{l}23.4 \% \\
(4356)\end{array}$ & $\begin{array}{l}20.1 \% \\
(3749)\end{array}$ \\
\hline \multirow[t]{5}{*}{ Inputs } & $\begin{array}{c}\text { Education } \\
\text { Primary }(67.0 \%)\end{array}$ & $\begin{array}{c}\text { Education } \\
\text { None }(100.0 \%)\end{array}$ & $\begin{array}{c}\text { Education } \\
\text { None }(100.0 \%)\end{array}$ \\
\hline & $\begin{array}{l}\text { Ever given birth } \\
\text { No }(100.0 \%)\end{array}$ & $\begin{array}{l}\text { Ever given birth } \\
\text { Yes }(100.0 \%)\end{array}$ & $\begin{array}{l}\text { Ever given birth } \\
\text { Yes }(100.0 \%)\end{array}$ \\
\hline & $\begin{array}{l}\text { logage } \\
3.05\end{array}$ & $\begin{array}{l}\text { logage } \\
3.39\end{array}$ & $\begin{array}{l}\text { logage } \\
3.44\end{array}$ \\
\hline & $\begin{array}{l}\text { Marital/Union status } \\
\text { Currently married/in } \\
\text { union }(100.0 \%)\end{array}$ & $\begin{array}{l}\text { Marital/Union status } \\
\text { Currently married/in } \\
\text { union }(100.0 \%)\end{array}$ & $\begin{array}{l}\text { Marital/Union status } \\
\text { Formerly married/in } \\
\text { union }(100.0 \%)\end{array}$ \\
\hline & $\begin{array}{l}\text { Wealth index } \\
\text { quintiles } \\
\text { Poorest }(31.1 \%)\end{array}$ & $\begin{array}{c}\text { Wealth index } \\
\text { quintiles } \\
\text { Poorest }(46.6 \%)\end{array}$ & $\begin{array}{l}\text { Wealth index } \\
\text { quintiles } \\
\text { Second }(29.3 \%)\end{array}$ \\
\hline
\end{tabular}

Fig. 5: Clusterd 
Model Summary

\begin{tabular}{|l|l|}
\hline Algorithm & TwoStep \\
\hline Inputs & 5 \\
\hline Clusters & 4 \\
\hline
\end{tabular}

\section{Cluster Quality}

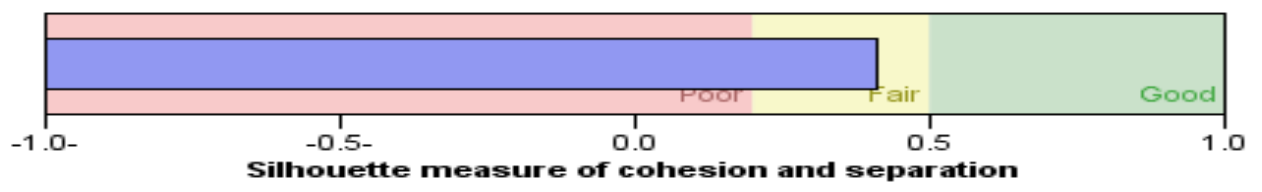

Fig. 6: Model Summary Imputation

\section{Clusters}

Input (Predictor) Importance

$\square 1.0 \square 0.8 \square 0.6 \square 0.4 \square 0.2 \square 0.0$

\begin{tabular}{|c|c|c|c|}
\hline Cluster & $-1.79769 e+308$ & 2 & 1 \\
\hline \multicolumn{4}{|l|}{ Label } \\
\hline \multicolumn{4}{|l|}{ Description } \\
\hline Size & \begin{tabular}{|}
$\mathbf{a 2} .0 \%$ \\
$(\mathbf{8 0 4 8 )}$
\end{tabular} & $\begin{array}{l}26.9 \% \\
(5167)\end{array}$ & $\begin{array}{r}9.3 \% \\
(1786)\end{array}$ \\
\hline \multirow[t]{5}{*}{ Inputs } & $\begin{array}{c}\text { Education } \\
\text { Primary (67.0\%) }\end{array}$ & $\begin{array}{l}\text { Education } \\
\text { None }(77.5 \%)\end{array}$ & $\begin{array}{c}\text { Education } \\
\text { None }(100.0 \%)\end{array}$ \\
\hline & $\begin{array}{l}\text { Ever given birth } \\
\text { No }(100.0 \%)\end{array}$ & $\begin{array}{l}\text { Ever given birth } \\
\text { Yes }(100.0 \%)\end{array}$ & $\begin{array}{l}\text { Ever given birth } \\
\text { Yes }(100.0 \%)\end{array}$ \\
\hline & $\begin{array}{l}\text { logage } \\
3.06\end{array}$ & $\begin{array}{l}\text { logage } \\
3.39\end{array}$ & $\underset{3.44}{\log a g e}$ \\
\hline & $\begin{array}{l}\text { Marital/Union status } \\
\text { Currently married/in } \\
\text { union }(100.0 \%)\end{array}$ & $\begin{array}{c}\text { Marital/Union status } \\
\text { Currently married/in } \\
\text { union }(100.0 \%)\end{array}$ & $\begin{array}{l}\text { Marital/Union status } \\
\text { Formerly married/in } \\
\text { union }(100.0 \%)\end{array}$ \\
\hline & $\begin{array}{l}\text { Wealth index } \\
\text { quintiles } \\
\text { Poorest }(25.2 \%)\end{array}$ & $\begin{array}{l}\text { Wealth index } \\
\text { quintiles } \\
\text { Poorest }(51.2 \%)\end{array}$ & $\begin{array}{l}\text { Wealth index } \\
\text { quintiles } \\
\text { Poorest }(61.1 \%)\end{array}$ \\
\hline
\end{tabular}

Fig. 7: Clusters

Imputation Number $=4$ 


\section{Model Summary}

\begin{tabular}{|l|l|}
\hline Algorithm & TwoStep \\
\hline Inputs & 5 \\
\hline Clusters & 2 \\
\hline
\end{tabular}

Cluster Quality

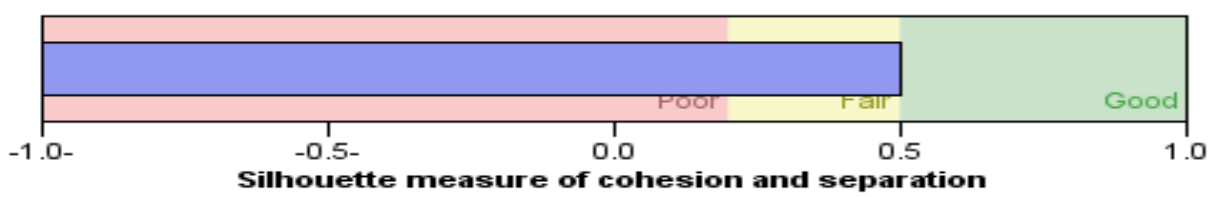

Fig. 8: Model Summary Imputation

\section{Clusters}

Input (Predictor) Importance

$\square 1.0 \square 0.8 \square 0.6 \square 0.4 \square 0.2 \square 0.0$

\begin{tabular}{|c|c|c|}
\hline Cluster & 2 & 1 \\
\hline \multicolumn{3}{|l|}{ Label } \\
\hline \multicolumn{3}{|l|}{ Description } \\
\hline Size & $\begin{array}{r}69.3 \% \\
(18333) \\
\end{array}$ & $\begin{array}{l}30.7 \% \\
(8126)\end{array}$ \\
\hline \multirow[t]{5}{*}{ Inputs } & $\begin{array}{l}\text { Education } \\
\text { None }(71.1 \%)\end{array}$ & $\begin{array}{l}\text { Education } \\
\text { Primary }(66.9 \%)\end{array}$ \\
\hline & $\begin{array}{l}\text { Ever given birth } \\
\text { Yes }(100.0 \%)\end{array}$ & $\begin{array}{l}\text { Ever given birth } \\
\text { No }(100.0 \%)\end{array}$ \\
\hline & $\underset{3.40}{\operatorname{logage}}$ & $\begin{array}{l}\text { logage } \\
3.06\end{array}$ \\
\hline & $\begin{array}{l}\text { Marital/Union status } \\
\text { Currently married/in } \\
\text { union }(60.8 \%)\end{array}$ & $\begin{array}{l}\text { Marital/Union status } \\
\text { Currently married/in } \\
\text { union (100.0\%) }\end{array}$ \\
\hline & $\begin{array}{l}\text { Wealth index } \\
\text { quintiles } \\
\text { Poorest }(25.8 \%)\end{array}$ & $\begin{array}{c}\text { Wealth index } \\
\text { quintiles } \\
\text { Poorest }(25.4 \%)\end{array}$ \\
\hline
\end{tabular}

Fig. 9: Cluster

Imputation Number $=5$ 
Model Summary

\begin{tabular}{|l|l|}
\hline Algorithm & TwoStep \\
\hline Inputs & 5 \\
\hline Clusters & 4 \\
\hline
\end{tabular}

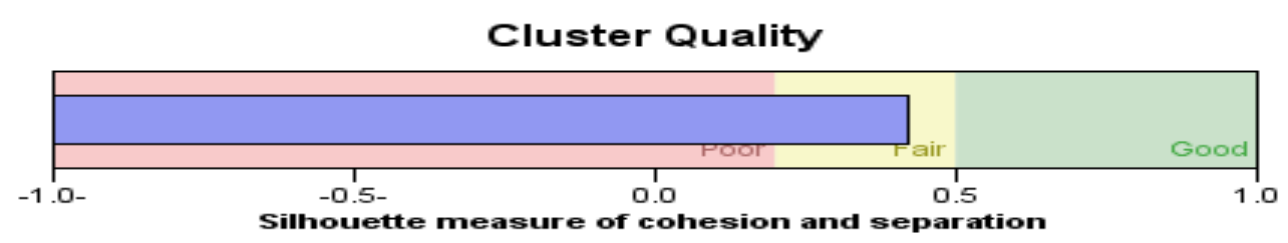

Fig. 10: Model Summary Imputation

\section{Clusters}

Input (Predictor) Importance

$\square 1.0 \square 0.8 \square 0.6 \square 0.4 \square 0.2 \square 0.0$

\begin{tabular}{|c|c|c|c|}
\hline Cluster & 1 & $-1.79769 e+308$ & 2 \\
\hline \multicolumn{4}{|l|}{ Label } \\
\hline \multicolumn{4}{|l|}{ Description } \\
\hline Size & $\begin{array}{l}27.5 \% \\
(6361)\end{array}$ & $\begin{array}{l}35.7 \% \\
(9366)\end{array}$ & $\begin{array}{l}17.1 \% \\
(3964)\end{array}$ \\
\hline \multirow[t]{5}{*}{ Inputs } & $\begin{array}{l}\text { Education } \\
\text { None }(61.8 \%)\end{array}$ & $\begin{array}{c}\text { Education } \\
\text { None }(100.0 \%)\end{array}$ & $\begin{array}{c}\text { Education } \\
\text { None }(100.0 \%)\end{array}$ \\
\hline & $\begin{array}{l}\text { Ever given birth } \\
\text { Yes }(100.0 \%)\end{array}$ & $\begin{array}{l}\text { Ever given birth } \\
\text { Yes }(100.0 \%)\end{array}$ & $\begin{array}{l}\text { Ever given birth } \\
\text { Yes }(100.0 \%)\end{array}$ \\
\hline & $\begin{array}{l}\text { logage } \\
3.42\end{array}$ & $\begin{array}{l}\text { logage } \\
3.39\end{array}$ & $\begin{array}{c}\text { logage } \\
3.39\end{array}$ \\
\hline & $\begin{array}{l}\text { Marital/Union status } \\
\text { Formerly married/in } \\
\text { union }(100.0 \%)\end{array}$ & $\begin{array}{l}\text { Marital/Union status } \\
\text { Currently married/in } \\
\text { union }(100.0 \%)\end{array}$ & $\begin{array}{l}\text { Marital/Union status } \\
\text { Currently married/in } \\
\text { union }(100.0 \%)\end{array}$ \\
\hline & $\begin{array}{l}\text { Wealth index } \\
\text { quintiles } \\
\text { Second }(28.5 \%)\end{array}$ & $\begin{array}{l}\text { Wealth index } \\
\text { quintiles } \\
\text { Second }(44.7 \%)\end{array}$ & $\begin{array}{c}\text { Wealth index } \\
\text { quintiles } \\
\text { Poorest }(53.2 \%)\end{array}$ \\
\hline
\end{tabular}

Fig. 11: Cluster

\section{Conclusions}

This study focuses on missing data treatment on cluster performed on Sudan Household survey. Initially, missing data mechanism and treatment rules are presented. Using the multiple imputation procedures. Two-Step Cluster Analysis is chosen over a wide range of approaches of statistical pattern-recognition available for clustering household health data. When there is limited generalisability outside of the available sample, the available data is excessively fit in an analysis and over-fitting occurs. Classification over-fitting can occur because their present an excessive number of 'noise' variables, or because the sample size is inadequate relative to the number of variables, or because the participants lack representativeness. Cluster analysis often faces the inadequate consensus about appropriate sample size ratios and considerable debate about over-fitting in statistical classification. However, authors have argued that each independent 
variable have a minimum of ten events to avoid over-fitting in other forms of multivariable analysis. Prior to cluster analysis, log transformation will be approximate normality in the data because household data does not follow the strict assumption of Two-Step Cluster Analysis that is the interval data have normal distribution. However, determination of interquartile ranges and median does not require the data to follow normal distribution hence raw data is applicable for obtaining these statistics. Clustering variables are assumed to be independent in Two-Step cluster analysis, and many other diverse traditional clustering techniques and analysis. The variables that form clusters thus have a low correlation (co linearity) between each other. Conditional correlation (conditional on membership in one or more clusters) and global correlation (between the variables entered into the analysis) are the possible forms of this co linearity. Specific diagnostic techniques for different techniques of cluster analysis are required for conditional correlation while calculation for global correlation is easy.

\section{Acknowledgement}

I would take this opportunity to thank my research supervisor, family and friends for their support and guidance without which this research would not have been possible.

\section{References}

[1] R. H. Henderson, T. Sundaresan, Cluster sampling to assess immunization coverage: a review of experience with a simplified sampling method, Bulletin of the World Health Organization 60(2) (1982) 253-260.

[2] R. J. Little, D. B. Rubin, Statistical analysis with missing data, John Wiley \& Sons, (1987).

[3] A. Williams, Science or marketing at Who? A Commentary on 'World Health 2000', Health Economics, 10(2) (2000)93-100. http://dx.doi.org/10.1002/hec.594.

[4] A. M. Aalto, U. Häkkinenm, E.Ollila, Measuring the responsiveness of health care system in the World Health Report 2000. In Eds The World Health Report 2000: What does it tell us about health systems? Analyses by Finnish Experts. Helsinki, Finland: National Research and Development Centre for Welfare and Health (STAKES). [http://www.stakes.fi/english/publicati/Publications.htm]. (2000)

[5] R. Little, D. Rubin, Statistical Analysis With Missing Data (2nd ed.), New York: Wiley, (2002). http://dx.doi.org/10.1002/9781119013563.

[6] R. Blendon, M. Kim, and J. M. Benson, The public versus the World Health Organization on health system performance. Health Affairs, 20(3) (2001)10-20. http://dx.doi.org/10.1377/hlthaff.20.3.10.

[7] V. Navarro, World Health Report 2000: Response to Murray and Frenk. Lancet, 357(9269) (2001)1701-1702. http://dx.doi.org/10.1016/S0140-6736(00)04827-3.

[8] P. D. Allison, Missing Data, SAGE University Papers (2002)

[9] J. L. Schafer Analysis of Incomplete Multivariate Data, New York: Chapman \& Hall, (1997).

[10] J. G. Ibrahim, "Incomplete Data in Generalized Linear Models," Journal of the American Statistical Association, 85(1990) 765-769. http://dx.doi.org/10.1080/01621459.1990.10474938.

[11] R. J. A. Little, "Regression with Missing X’s: A Review," Journal of the American Statistical Association, 87(1992)1227-1237. http://dx.doi.org/10.2307/2290664.

[12] S. Greenland, W. D. Finkle, "A Critical Look at Methods for Handling Missing Covariates in Epidemiologic Regression Analyses," American Journal of Epidemiology, 142 (1995) 1255-1264.

[13] M. Jones, "Indicator and Stratification Methods for Missing Explanatory Variables in Multiple Linear Regression," Journal of the American Statistical Association, 91 (1996) 222-230. http://dx.doi.org/10.1080/01621459.1996.10476680.

[14] I. Jansen, C. Bounces, G. Molenberghs, “Analyzing Incomplete Discrete Longitudinal Clinical Trial Data,” Statistical Science, 21(2006) 5269. http://dx.doi.org/10.1214/088342305000000322.

[15] R. J. Cook, L. Zeng, G. Y. Yi, "Marginal Analysis of Incomplete Longitudinal Binary Data: A Cautionary Note on LOCF Imputation," Biometrics, 60 (2004) 820-828. http://dx.doi.org/10.1111/j.0006-341X.2004.00234.x.

[16] J. Carpenter, M. Kenward, S. Evans, "Last Observation Carry-Forward and Last Observation Analysis," Statistics in Medicine, 23 (2004) 3241-3244. http://dx.doi.org/10.1002/sim.1891.

[17] D. B Rubin, "Inference and Missing Data," Biometrika, 63(1987)581-590. Multiple Imputations for Nonresponsive in Surveys, New York: Wiley. 8(1987) 3-15.Association, 91 (1976) 473-489.

[18] D. B. Rubin, "Multiple Imputation after 18+Years," Journal of the American Statistical (1996).

[19] J. Barnard, X. L. Meng, “Applications of Multiple Imputation in Medical Studies: From AIDS to NHANES," Statistical Methods in Medical Research, 8(1999) 17-36. http://dx.doi.org/10.1191/096228099666230705.

[20] P. D. Allison, "Imputation of Categorical Variables with PROC MI", Available online at http:// www2.sas.com/ proceedings/sugi30/ 11330.pdf [accessed July 30, 2006]. Multiple Imputation," The American Statistician, 57 (2005) 229-232.

[21] P. D. Allison, "Multiple Imputation for Missing Data: A Cautionary Tale," Sociological Methods and Research, 28(2000) 301-309. http://dx.doi.org/10.1177/0049124100028003003.

[22] J. L. Schafer, Analysis of Incomplete Multivariate Data, New York: Chapman \& Hall (1997). http://dx.doi.org/10.1201/9781439821862.

[23] Y. Bishop, S. Fienberg, P. Holland, Discrete Multivariate Analyses (1975).

[24] I. Olkin, R. F. Tate, "Multivariate Correlation Models With Mixed Discrete and Continuous Variables," The Annals of Mathematical Statistics, Theory and Practice, Cambridge, MA: MIT Press 32 (1961) 448-465. http://dx.doi.org/10.1214/aoms/1177705052.

[25] J. Carpenter, "Annotated Bibliography on Missing Data”, Available online at http://www.lshtm.ac.uk/ msu/ missingdata/biblio.html [accessed July 30, 2006].

[26] F. Xie, M. C. Paik, "Generalized Estimating Equation Model for Binary Outcomes With Missing Covariates,” Biometrics, 90 Statistical Software Reviews 53 (1997) 1458-1466.

[27] S. van Buuren, H. C. Boshuizen, D. L. Knook, "Multiple Imputation of Missing, (1999)

[28] T. E. Raghunathan, J. M. Lepkowski, P. Solenberger, “A Multivariate Technique for Multiply Imputing Missing Values Using a Sequence of Regression Models," Survey Methodology, 27(2001) 85-95.

[29] J. G. Ibrahim, M.-H. Chen, S. R. Lipsitz, "Missing- Data Methods for Generalized Linear Models: Comparative Review," Journal of the American Statistical Association, 100(2005) 332-346. http://dx.doi.org/10.1198/016214504000001844.

[30] M. S. Aldenderfer, R. K. Blashfield, Cluster analysis, Sage Publications, London, England, 
[31] R. M. Cormack, A review of classification, Journal of the Royal Statistical Society, Series A (General), 134 (1984) $321-367$. http://dx.doi.org/10.2307/2344237.

[32] P. Tan, M. Steinbach, V. Kumar, Introduction to data mining, Addison-Wesley, Networks, 16 (2005) 645-678.

[33] R. Duda, P. Hart, Pattern Classification and Scene analysis, John Wiley \& Sons, Inc, NY, (1973).

[34] J. Han, M. Kamber, Data mining: concepts and techniques, Morgan Kaufmann Publishers, Inc., (2001).

[35] A. Jain, M. Murty, P. Flynn, Data clustering: a review, ACM Computing Surveys, 31 (1999) 264-323. http://dx.doi.org/10.1145/331499.331504.

[36] C. Fraley, A. Raftery, Model-based clustering, discriminant analysis, and density estimation, Journal of the American Statistical Association, 97(2002) 611-631. http://dx.doi.org/10.1198/016214502760047131.

[37] A. K. Jain, R. Dubes, Algorithms for clustering data, Prentice-Hall, Inc., Upper Saddle River, NJ, USA: (1988).

[38] K. D. Bailey, Cluster analysis, Sociological Methodology, 6(1975) 59-128. http://dx.doi.org/10.2307/270894.

[39] D. Jiang, C. Tang, A. Zhang, Cluster analysis for gene expression data: A survey, IEEE Transactions on Knowledge and Data Engineering, 16 (2004) 1370-1386. http://dx.doi.org/10.1109/TKDE.2004.68.

[40] G. Milligan, M. Cooper, An examination of procedures for determining the number of clusters in a data set, Psychometrika, 50(1985) 159179. http://dx.doi.org/10.1007/BF02294245.

[41] Kish, Leslie, Survey Sampling, New York: John Wiley \& Sons, Inc, (1965).

[42] A. Rose, R. F. Grais \& H. Ritter. A comparison of cluster and systematic sampling methods for measuring crude mortality. Bulletin of the World Health Organization, 84(2006) 290-296. http://dx.doi.org/10.2471/BLT.05.029181. 